\title{
Creating Shared Value at Dutch-Bangla Bank Limited in Bangladesh
}

\author{
Md. Rabiul Islam ${ }^{1}$, Md. Tahidur Rahman ${ }^{2, ~ *, ~ S y e d ~ Z a b i d ~ H o s s a i n ~}{ }^{3}$ \\ ${ }^{1}$ Department of Humanities, Rajshahi University of Engineering \& Technology (RUET), Rajshahi, Bangladesh \\ ${ }^{2}$ Department of Business Administration, EXIM Bank Agricultural University Bangladesh, Chapainawabganj, Bangladesh \\ ${ }^{3}$ Department of Accounting and Information Systems, University of Rajshahi, Rajshahi, Bangladesh
}

\section{Email Address:}

rabi54mba@yahoo.com (Md. R. Islam), towhidais@gmail.com (Md. T. Rahman), syed6205@gmail.com (S. Z. Hossain)

${ }^{*}$ Corresponding author

\section{To cite this article:}

Md. Rabiul Islam, Md. Tahidur Rahman, Syed Zabid Hossain. Creating Shared Value at Dutch-Bangla Bank Limited in Bangladesh. American Journal of Theoretical and Applied Business. Vol. 3, No. 3, 2017, pp. 54-63. doi: 10.11648/j.ajtab.20170303.13

Received: August 30, 2017; Accepted: September 15, 2017; Published: October 17, 2017

\begin{abstract}
The Creating Shared Value (CSV) concept (creating business value through creating social value by addressing societal unmet needs and challenges) has been appeared as a new way of doing responsible business in the world and formed the core of recent business research. The study strives to investigate reflective insights into the Porter and Kramer's CSV concept taking evidence from Dutch-Bangla Bank Limited (DBBL) in Bangladesh. The results show that DBBL has been creating shared value through its innovative products and services like mobile financial services, school banking, and agricultural, SME and environment friendly banking. The results also indicate that DBBL has been creating shared value along the three areas of Porter and Kramer's CSV concept but mostly through reconceiving products and services, and redefining value chain to improve productivity. Taken as a whole, DBBL has been sharing its CSV with different stakeholders for mutual benefits.
\end{abstract}

Keywords: Banking on Shared Value, Banking Sector, Corporate Social Responsibility (CSR), Creating Shared Value (CSV), Shared Value

\section{Introduction}

The idea of Creating Shared Value (CSV) was introduce by Michael E. Porter and Mark R. Kramer [1] in their article "Strategy and Society: The Link between Competitive Advantage and Corporate Social Responsibility" that won the McKinsey Award in 2006for the Best Harvard Business Review Article. The authors explained the new approach to socially responsible business practices- the concept of CSV as creating economic value in a way that also creates value to the society by addressing societal needs and challenges [2]. The novel idea was also published in another Harvard Business Review (HBR) article "The Big Idea: Creating Shared Value; How to Reinvent Capitalism - and Unleash a Wave of Innovation and Growth." The idea was further expanded by several subsequent researches such as "Creating Shared Value: A How-to Guide for the New Corporate (R) Evolution;" "Innovating for Shared Value: Companies that Deliver both Social Benefit and Business Value Rely on Five Mutually Reinforcing Elements;" "Measuring
Shared Value: How to Unlock Value by Linking Social and Business Results;" and "Banking on shared value: How banks profit by rethinking their purpose" [3, 4, 5, 6]. The aforementioned articles provide insights and relevant examples of companies that have already developed deep links between their business interest and social interest concurrently.

The theme of CSV is that the competitiveness of a company and the health of the communities around it are dependent on each other. Recognizing and capitalizing on these connections between societal and economic progress is the power to unleash the next wave of global growth and to redefine capitalism [2]. Porter and Kramer [2] held that businesses can create shared value opportunities by reconceiving products and services, by redefining value chain activities to improve productivity, and by building supportive industry clusters at the company's locations. In order to create social and business value, five elementssocial purpose, a defined need, measurement, the right innovation structure, and co-creation are essential [4]. The authors observed that these five elements of creating shared 
value reinforce one another. They mentioned that social purpose helps a firm identify the needs it might want to address, because understanding a region's particular needs helps define what can be improved and by how much, and the value of that change to the business. The optimal innovation structure for the social venture relies on the degree to which the potential for shared value can be anticipated and aligned with the company's financial criteria. And the requirements for delivering both business and social value, in turn, establish which capabilities are needed from new hires or external partners [4].

The present study has conceptualized CSV in banking as the policies and practices that take into account manifest social problems as business opportunities in order to create shared value- value for both the society and the banks concurrently. In practice, the social problems that provide opportunities for banks to create shared value include but are not limited to: inadequate banking access; inadequate credit facilities for SMEs, agriculture, and rural customers; difficulties of money transfer in rural areas; inadequate banking knowledge of stakeholders; lack of trust in banking activities; unemployment situations in the country; environmental footprint; and so on. Banks can take into account these social problems as business opportunity through providing banking access to the unbanked or under-banked people, providing adequate credit to rural agricultural and SMEs, providing credit for the firms of women entrepreneurs, launching environmental friendly investment, educating stakeholders, engaging in trust-building activities, boosting up productivity in the value chain, showing concern for employees, creating direct and indirect employment opportunities, helping the distressed and vulnerable people, and launching banking products to meet many other unmet and less addressed social and environmental needs and challenges. Hence, business value is attained through improved profitability, productivity, market share, quality, goodwill, brand image, and reduced operating costs and resource use. While, social value is counted through improved job creation, banking access, beneficiary income, regulatory compliance, government income, customer and employee learning, responsible and ethical banking, less environmental footprint and many more. Thus, the purpose of the study is to investigate reflective insights into the Porter and Kramer's CSV concept taking evidence from Dutch-Bangla Bank Limited (DBBL) in Bangladesh. The specific objectives to attain the goal of the study are: (1) to comprehend the extent to which DBBL is creating shared value through product and service innovation; (2) to figure out DBBL's initiatives along the different areas of CSV; and (3) to visualize how DBBL is sharing its CSV with stakeholders.

\section{Literature Review}

There has been a broad debate as to the efficacy of corporate social responsibility (CSR) efforts. Some scholars argued that CSR efforts are good for society, even if they don't really benefit the shareholders of the firm. Others suggested that corporate social efforts can have positive impacts on the long-term profitability of the firm. Still others proposed corporate social efforts do not actually generate positive returns for the firm or to the society as a whole [6]. CSR efforts are sometimes criticized as nothing more than 'window dressing', 'blue washing', 'green washing' or a 'giant public relations campaign' [7]. Corporate responsibility generally refers to 'CSR activities' and 'sustainable enterprising' [8], which have been criticized because of the disconnection from firms' profit generating business $[1,2,9]$. Theories on value creation emphasize how value is perceived individually and should be created with regard to the recipient [10]. In order to create value, a company must possess a competitive advantage over its competitors. Similarly, Porter and Kramer [11] mentioned that philanthropy should be used to improve a company's competitive context. Although, CSR has increased global interests, the response to this has not been productive. The reasons why CSR could not be made productive are that the government, social activists and media pit business against society, when clearly the two are interdependent and that they put pressures on companies to think of CSR in a generic way rather than tailoring CSR according to a company's strategic needs [1].

Despite its appeal and uptake in corporate and philanthropic circles, shared value merely advances the conventional rhetoric that what is good for business is good for society [12]. The shared value approach narrows what counts as social value and avoids the friction between business and society and as a consequence the approach is problematic as a framework for addressing sustainability and development, and an insufficient basis for decision-making about philanthropy and CSR [12]. Similarly, the concept suffers from some serious shortcomings, namely: it is unoriginal, it ignores the tensions inherent to responsible business activity, it is naïve about business compliance, and it is based on a shallow conception of the corporation's role in society [13]. Dembek et al. [14] in their paper highlighted that 'shared value' has spread into the language of multiple disciplines, but they argued that the CSV concept is vague as it presents important discrepancies in the way it is defined and operationalized.

Likewise, Beschorner [15] argued that "Porter's and Kramer's criticism and rejection of corporate social responsibility depends upon the straw man concept of CSR and their ultimate reliance on economic arguments is too normatively thin to do the important work of reconnecting businesses with society and as a result, prospects for a genuine reinvention of capitalism lie elsewhere". Also, Williams and Hayes [16] in their paper mentioned that there is a need to go a step further and attempt to establish the linkages between pursuing core business model and the subsequent impact on both business and social indicators.

Lapina, Borkus, and Starineca [17] mentioned that "While there is no disagreement as to the role and importance of social responsibility in business, there is no unanimous opinion as to how these activities go together with the organizational goals and day-to-day activities, and how extensive they should be." The authors argued that "CSV provides some insight into this by strongly linking the social activities to company goals and positioning social responsibility as internal function rather than external obligation to society" [17]. CSV can be used as the way to integrate social goals with business practice without 
hampering a firm from its primary goal of earning profit [2]. The CSV approach has evolved as a supersede approach to CSR because in CSV, social and environmental benefits are integrated to the core business choices of firm, it is done internally rather than due to external pressures, it directly enhances the competitive positioning without distracting firm from profitability, and it changes the standpoint of business organization in a way that social welfare is a prerequisite for doing well in business [2].

CSV concept has gained credibility, legitimacy and popularity in the world as a new mode of doing business and formed the core of most recent business research and practice [18]. One the on hand, the concept has been adopted by many of the world's leading corporations namely Intel, Nestle, Unilever, Coca-Cola, and Western Union, on the other hand, the framework and language of shared value has spread from the private sector to public sectors, NGOs, civil society and academia [18]. Bank and financial institutions around the globe are also applying the CSV concept. They include, but are not limited to "Banco de Credito e Inversiones, Bank of America, Merrill Lynch, Barclays, Bendigo Bank, Citigroup, Credit Suisse, Dhaka Bank, Goldman Sachs, ING, ItaúUnibanco, JPMorgan Chase, National Australia Bank, Rabobank, Standard Bank, and Vancity" [19].

\section{Methodology of the Study}

The study is exploratory in nature that has used both qualitative and quantitative information mainly related to innovative banking products and services that have been creating shared value- a newly advent concept developed and propagated by Porter and Kramer. Data has been collected solely from secondary sources which include relevant articles, dissertations, corporate annual reports and official websites. Out of 22 conventional private commercial banks listed on the Dhaka Stock Exchange Ltd (DSE), the study has selected DBBL considering: (1) availability of banking services and products that are creating shared value, (2) spread out of operating branches, (3) integration of social and environmental concern into core banking operations, and (4) integration of social activism into mission, vision and core objectives.

\section{Overview of DBBL}

DBBL is a publicly traded scheduled commercial bank operating in Bangladesh. It was founded as a joint venture between Bangladesh and Netherlands. It was incorporated as a public limited company under the Companies Act 1994 and commenced its banking business with one branch on June 03, 1996. The share holding position of the bank as on June 30, 2016 was: Sponsor/Director 87 percent, Institute 6.72 percent, Foreign 0.48 percent, and general public of the country 5.80 percent [20]. Between 2011 and 2015 the bank reported paidup capital BDT 2,000 million as against authorized capital of BDT 4,000 million. As Table-1 shows, the bank's total deposits, number of deposit account holders, total loans \& advances, and number of loan account holders had shown an uninterrupted growth (almost doubled) during the study period.

Table 1. Basic Information of DBBL.

\begin{tabular}{|c|c|c|c|c|c|}
\hline \multirow{2}{*}{ Particular } & \multicolumn{5}{|c|}{ Year-Wise Data (Amount in Million BDT) } \\
\hline & 2011 & 2012 & 2013 & 2014 & 2015 \\
\hline Total deposit & 100,711 & 125,433 & 145,230 & 166762 & 186765 \\
\hline Number of deposit account holders & $2,026,189$ & $2,755,149$ & $3,405,671$ & $3,795,255$ & $4,444,747$ \\
\hline Total loans and advances & $79,660.70$ & $91,648.90$ & $106,422.80$ & 124423.00 & 152270.00 \\
\hline Number of loan account holders & 15,595 & 24,650 & 26,052 & 26,268 & 26,936 \\
\hline Net asset value/share (NAV) & 44.7 & 54.3 & 63.2 & 72.6 & 83.8 \\
\hline EPS as against face value of BDT 10 & 10.8 & 11.6 & 10.0 & 11.0 & 15.1 \\
\hline Number of employees & 4,015 & 5,268 & 4,666 & 5,556 & 5,201 \\
\hline
\end{tabular}

Source: Compiled by the researcher from the Annual Reports of DBBL, 2011-15.

Table 2. Branches, ATM and Fast Track Information of DBBL.

\begin{tabular}{llllll}
\hline \multirow{2}{*}{ Particular } & \multicolumn{6}{l}{ Year-Wise Data (in Numbers) } \\
\cline { 2 - 6 } & $\mathbf{2 0 1 1}$ & $\mathbf{2 0 1 2}$ & $\mathbf{2 0 1 3}$ & $\mathbf{2 0 1 4}$ & $\mathbf{2 0 1 5}$ \\
\hline Branches & 111 & 126 & 136 & 145 & 155 \\
ATM units & 1,940 & 2,366 & 2,454 & 2,705 & 3,588 \\
Fast tracks & 153 & 235 & 263 & 365 & 524 \\
\hline
\end{tabular}

Source: Compiled by the researchers from the Annual Reports of DBBL, 2011-15.

DBBL has registered a continuous growth in Earning per Share (EPS), which was BDT 10.8 as against face value of BDT 10 in 2011 and stands at BDT 15.1 in 2015. The bank paid 40 percent cash dividend each year during the study period. DBBL showed a remarkable growth in its Net Asset Value per share, which was BDT 44.7 as against face value of
BDT 10 in 2011 and rapidly increased to BDT 83.8. Presently, the bank has 5,201 full time employees as against 4015 in 2011. All these information depict the strength of operating performance of DBBL.

$\mathrm{DBBL}$ is the pioneer in introducing the concept of branchless banking in the country with a huge numbers of ATMs in important places like airports, railway stations, markets, shopping malls, university campuses, branch premises and important public places. As Table 2 shows, the number of ATM units increased from 1,940 in 2011 to 3588 in 2015 or 84.94 percent increase in just five years. No other bank in Bangladesh has invested heavily in ATM infrastructure like DBBL has rather they have joined DBBL ATM infrastructure along with their limited own ATMs. In addition to its rapid expansion of ATM network, DBBL has introduced Fast Track in the country in November 2009 to 
offer branchless banking service. DBBL is also actively engaged in CSR programs in which it is strategically focuses on education and healthcare sectors.

It is apparent from Table 3 that DBBL also has been extending its contribution to national exchequer progressively. In 2015, the bank paid BDT 3,223 million as corporate taxes, which was 41.35 percent more than that of the year 2011. The bank is investing in the industry, SMEs, and agricultural sectors among others and in this way assisting the country's economic and social wellbeing.

Table 3. Contribution of DBBL to National Exchequer.

\begin{tabular}{llllll}
\hline \multirow{2}{*}{ Particular } & \multicolumn{5}{l}{ Year-Wise Data (Amount in Million BDT) } \\
\cline { 2 - 6 } & $\mathbf{2 0 1 1}$ & $\mathbf{2 0 1 2}$ & $\mathbf{2 0 1 3}$ & $\mathbf{2 0 1 4}$ & $\mathbf{2 0 1 5}$ \\
\hline Payment to govt. exchequer & 2,280 & 2,497 & 2,179 & 2,698 & 3,223 \\
\hline
\end{tabular}

Source: Compiled by the researchers from the Annual Reports of DBBL, 2011-15.

\section{Shared Value Products at DBBL}

DBBL has been focusing the less addressed social needs and contributing to reducing environmental footprint through its innovative and entrepreneurial banking services. The bank has a wide selection of products and services to meet the needs of a wide range of customers. However, the following innovative banking products are selected for through and critical appraisal and these products are termed as 'Shared Value' products. They are Mobile Banking (Rocket), School banking, Agricultural, SME and Environment Friendly Banking.

\subsection{DBBL Mobile Banking}

Mobile banking is renamed as 'Rocket' in DBBL, which offers banking services to the customers through cell phone within the applicable rules, regulations and guidelines of the central bank of Bangladesh. DBBL launched this service on March 31, 2011 with the aim of bringing unbanked rural people into the commercial banking network. Mobile banking services are a part of main operations of the bank. Initially mobile banking services were made available in 46 SubDistricts of 6 Districts in the Dhaka division. During the last five years, the bank has expanded the service all over Bangladesh. DBBL is heavily dependent on agent network to extend financial services at the grass root level. Agents are serving the end customer and acting as a first contact point to deliver the mobile financial services.

DBBL is currently offering various products and services through mobile banking, which are: free customer registration or account opening, cash deposit, cash withdrawal, foreign remittance, salary/allowance disbursement, mobile balance recharge, person to person fund transfer, bill payment, merchant payment, collection account, ATM withdrawal, linkage between core banking \& mobile banking, balance inquiry, statement inquiry, sending money from mobile account to any DBBL card number, and payment through ecommerce. DBBL mobile banking has been popular payment disbursement solution for the corporate bodies and different government and private houses. Currently the bank is disbursing salaries and allowances to the employees or beneficiaries of different government organizations, garments factories, grants to the natural calamity affected people, insurance premium and claims, student's tuition fees admission fees, registration fees, exam fees etc.

Since its inception, DBBL mobile banking has achieved a remarkable growth in agent expansion, number of customers and transaction compare to previous years as shown in the Table 4. During the last five years (2011-15), DBBL registered an uninterrupted growth in customer accounts, which was 63,141 in 2011 reached to $6,755,128$ in 2015 , a 107 times increased. Hence, it is worth mentioning that the number of customer accounts was 3,690,269 in 2014 and increased to $6,755,128$ in 2015, doubled in just one year. As of December 31,2015 the bank reported a total of 216 corporate clients are using the mobile financial services for payment of salaries of their employees. To address the untapped and unprivileged market, agent points was also expanded. DBBL started its mobile financial services with 1194 agents in 2011 and the number increased to 129,198 agent points in 2015, an unbelievable 108 times growth in just five years. The agent growth was concurrently with the growth of customers. As of 2015, a total of 662 field staff, 77 mobile banking offices, 155 DBBL branches, 4000 merchants and 3,588 ATM units and partner's bank branches were also working as mobile banking access channel for the customers.

Table 4. Performance of DBBL Mobile Banking.

\begin{tabular}{|c|c|c|c|c|c|}
\hline \multirow{2}{*}{ Sources } & \multicolumn{5}{|c|}{ Year-Wise Data } \\
\hline & 2011 & 2012 & 2013 & 2014 & 2015 \\
\hline Total no of mobile bank accounts & 63,141 & 843,116 & $2,010,283$ & $3,690,269$ & $6,755,128$ \\
\hline Total no of agent points & 1194 & 20571 & 62572 & 110866 & 129198 \\
\hline No of corporate clients for salary payment & 0 & 40 & 83 & 173 & 216 \\
\hline Field staff & 418 & 998 & 849 & 751 & 662 \\
\hline ATM units & 1,940 & 2,366 & 2,454 & 2,705 & 3,588 \\
\hline Mobile bank office & 151 & 368 & 302 & 77 & 77 \\
\hline General branches & 111 & 126 & 136 & 145 & 155 \\
\hline
\end{tabular}

Source: Compiled by the researchers from the Annual Reports of DBBL, 2011-15.

DBBL has been creating shared value (value for business and society and/or environment) through its mobile financial services. The bank has been creating business value through incremental revenues from the services. DBBL mobile 
banking has been creating value for the society and environment in the following ways:

a. Banking for the Unbanked: "Despite a large number of bank branches and microfinance institutions in Bangladesh, 49.56 percent of the adult people are unbanked" [16]. The unbanked rural poor people have limited access to commercial banking services because of high transaction costs. Moreover, minimum balance requirements as well as unwillingness of commercial banks to perform token size transactions keep rural people away from bank. Furthermore, urbanized operations of commercial banks have aggravated the problems. Mobile banking, however, has opened the door for the unbanked segments who were isolated for so long from commercial banking services. The service charge is also low.

b. Customer Convenience: Mobile banking services provide customer convenience as the service already expanded all over Bangladesh through enriched agent networks, mobile bank offices, merchant shops, and DBBL branches. The service is now at the foot step of customers.

c. Employment Generation: DBBL operates its mobile banking business through involving local community. As a result, a big employment opportunity has been created at different parts of Bangladesh. As of 2015, a total of 662 field staff was directly employed by the bank and self-employment opportunities were created for 129,198 agents.

d. Increasing Savings: DBBL is paying interest on the deposited amount for the mobile banking accounts. It helps increase the habit of savings particularly among the unbanked segments. The savings habit helps the formation of domestic capital.

e. Employee Skill Development: DBBL has been arranging regular training and development programs for its mobile banking field staff in order to create a professional and skilled workforce.

f. Pollution Free Banking: Mobile banking service of DBBL refrain customers from directly coming to the distant bank places, thus reducing carbon emission from vehicle use. It also protect environment through paper less banking.

\subsection{DBBL School Banking}

As a part of the product innovation, DBBL launched school banking for the unbanked school going children in March 2011 with the aim of inspiring the habit of contemporary banking practices at an early age. A student aged between 6 and 18 years can open a 'student savers account' with a minimum deposit of BDT 100. With the account a student get ATM service, debit card service, and mobile banking service totally free of cost. The account does not require students to pay yearly account maintenance fee or debit card renewal fee. Moreover, students get interest on the savings amount. The account can be operated jointly with guardian as well. The school banking product of DBBL is gradually getting popularity. As shown in the table 5, the number of school banking accounts has been increasing rapidly over the years. Up to 2015, the number of school banking accounts stood at 98,328, which was 20,418 in 2013, almost five times increase in just two years.

Table 5. Growth in DBBL School Banking Accounts.

\begin{tabular}{llll}
\hline \multirow{2}{*}{ Sources } & \multicolumn{3}{l}{ Year wise data } \\
\cline { 2 - 4 } & $\mathbf{2 0 1 3}$ & $\mathbf{2 0 1 4}$ & $\mathbf{2 0 1 5}$ \\
\hline Number of school banking accounts & 20,418 & 60,486 & 98,328 \\
Growth from previous year (in percentage) & - & 196.23 & 62.56 \\
\hline
\end{tabular}

Source: Compiled by the researchers from the Annual Reports of DBBL, 2013-15.

DBBL's business value from this innovative product is the accumulated savings that is invested at a required rate of return. The students after eighteen years of age can shift their account as a normal savings account, which ensure future customer base of the bank as well. Besides, the bank is collaborating with educational institutions for assisting them to get payment of tuition fees, admission fees, exam fees, registration fees etc from students. DBBL, through its school banking facilities, is also creating social value as it is the best way to encourage the savings aptitude of the unbanked school going students and to help a student learn how to budget, account for, and manage his/her own fund for higher education. Moreover, through national school banking conferences, the bank is creating social awareness on financial matters.

\subsection{Agricultural Investment of DBBL}

The central bank of Bangladesh has designed and directed an agricultural credit policy for the PCBs by giving priority to three core sectors: Crop, Fisheries, and Poultry \& Livestock. The central bank suggested commercial banks to prioritize underdeveloped and neglected regions of the country including Char (river basin), Haor (large water logging area) and coastal areas. In line with Bangladesh Bank directives, DBBL has been disbursing agricultural credit through using NGO/MFI linkage as well as through its own branch network to the underdeveloped and neglected areas so that actual small farmers and share-croppers can get hassle-free agricultural credit on single customer/group based lending. However, due to lack of adequate rural branches, the bank is heavily dependent on NGOs/MFIs linkage to provide micro-finance in the agricultural sector. In addition to MFIs linkage DBBL has also been extending agricultural credit through its own branches by using 'contract farming system' ${ }^{\text {'1 }}$ between farmers and manufacturing firms. DBBL's contract farming credit disbursement is a notable step in rural credit allocation in order

\footnotetext{
${ }^{1}$ Contract Farming is a system developed for the production and supply of agricultural/horticultural products under forward contract between producers/suppliers and buyers. This mutual contract between the producing farmer and the large agricultural raw material user helps the producing farmer getting the proper market price as the system minimizes marketing expenses. In 2012, DBBL has extended BDT 200.00 million in the form of Overdraft Limit to PRAN Agro Ltd, a sister concern of PRAN RFL group which has introduced Contract Farming in the Northern part of Bangladesh. They accumulated 2,091 individual farmers under a center leader who have 255, 674 decimal of land and generally cultivate Paddy, Mug, Nut, Tomato, Mobs and Mangoes etc. PRAN Agro Ltd collects major portion of raw materials from native farmers and gives value to their activities (Source: DBBL Annual Report 2012, p. 164).
} 
to create shared value. The five-year performance of DBBL agricultural disbursement is represented in Table 6.

Table 6. Growth in Agricultural Disbursement of DBBL.

\begin{tabular}{llllll}
\hline \multirow{2}{*}{ Particular } & \multicolumn{5}{l}{ Year-Wise Data (Amount inMillion BDT) } \\
\cline { 2 - 6 } & $\mathbf{2 0 1 1}$ & $\mathbf{2 0 1 2}$ & $\mathbf{2 0 1 3}$ & $\mathbf{2 0 1 4}$ & $\mathbf{2 0 1 5}$ \\
\hline $\begin{array}{l}\text { Total } \\
\text { disbursement }\end{array}$ & $11,257.00$ & $5,486.91$ & $1,900.74$ & $1,978.70$ & $2,402.57$ \\
\hline
\end{tabular}

Source: Compiled by the researchers from the Annual Reports of DBBL, 2011-15.

Table 6 reveals that agricultural loan disbursement of DBBL was significantly dropped over the study period 20112015. It invested BDT 11,257 million in 2011 but reduced its investment reduced to BDT 2,402.57 million in 2015. The above table suggests that the bank is creating shared value to a limited extent through investing in the agriculture sector.

\subsection{SME Investment by DBBL}

DBBL has been constantly working for the betterment of the SME sector of the country since the inception of banking business. However, it has established a fully functional SME Division in 2008. The bank has opened 'SME help desk' and 'women entrepreneurs dedicated desk' in all of its operating branches. It has equipped each desk with efficient manpower in order to actively supporting SME sectors. By taking into account of the diverse financial needs of SME entrepreneurs, the bank has launched several SME products that are featured in the Table 7.

Table 7. Features of DBBL SME Products.

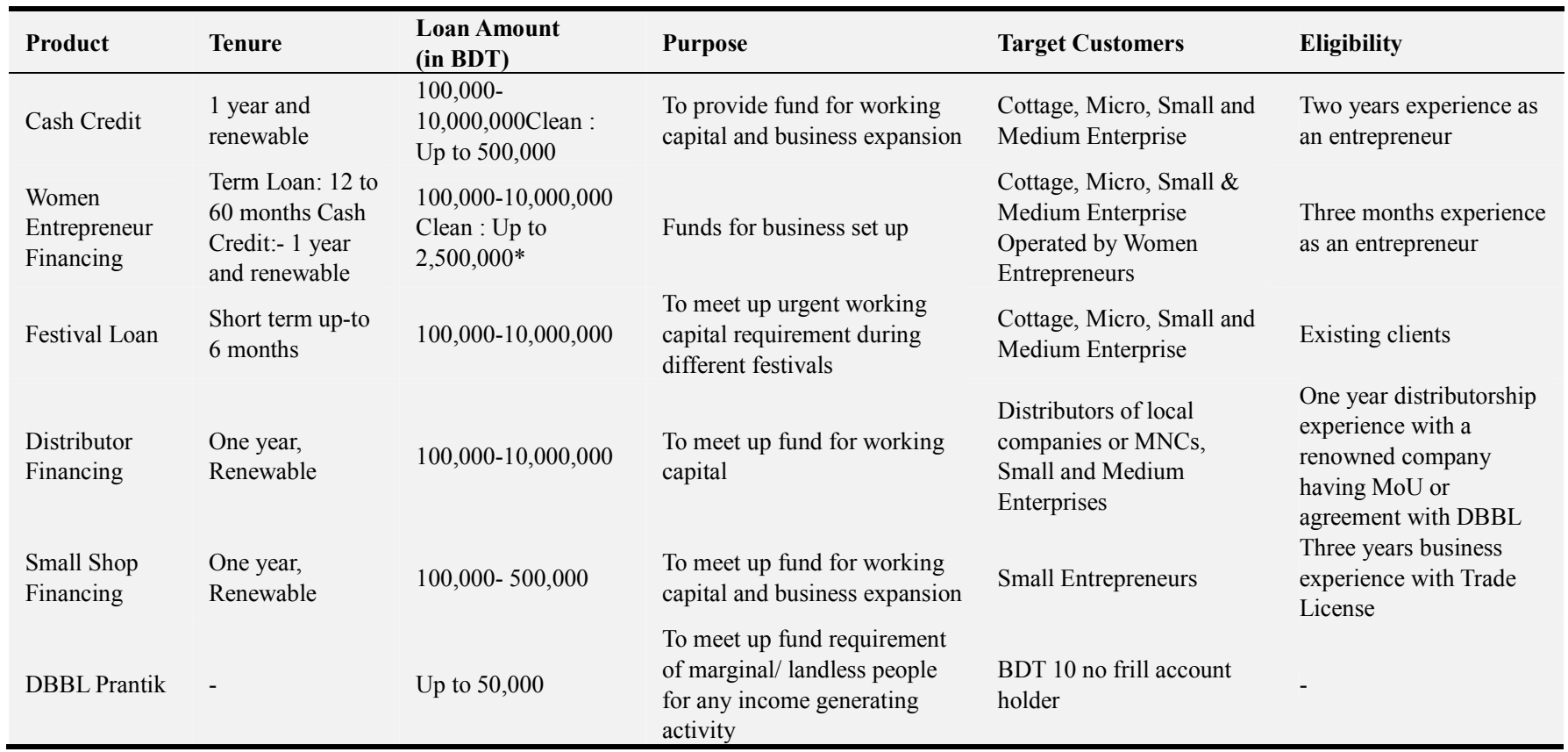

Source: Compiled by the researcher on the basis of information provided in the official websites of DBBL as on December 24, 2016

*Conditions: Financing depends on availability of BB refinance scheme.

Table 8 is an account of the investment made by DBBL in the SME sector development of the country. Table-8 shows slight ups and downs in investment in the SME sector during the study periods ranging from 2011 to 2015. It is observed that over the period total disbursement in absolute amount had an increasing but fluctuating trend from year to year. However, in relative term, total loans and advances to total SME disbursement had a fluctuating but decreasing trend. Although the bank increased its SME disbursement in 2015 as a matter of fact it was 21.76 percent of total loans and advances. Despite ups and downs in SME sector investment, the percentage of SME loan disbursement to total loans and advances was more than 20 percent throughout the period of study, which is not negligible and hence it is creating shared value.

Table 8. Growth in SME Disbursement of DBBL.

\begin{tabular}{lllll}
\hline \multirow{2}{*}{ Particular } & \multicolumn{4}{c}{ Year-Wise Data (Amount in Million BDT) } \\
\cline { 2 - 5 } & $\mathbf{2 0 1 1}$ & $\mathbf{2 0 1 2}$ & $\mathbf{2 0 1 3}$ & $\mathbf{2 0 1 4}$ \\
\hline Total SME disbursement & $30,868.00$ & $25,137.00$ & $32,284.00$ & $28,225.20$ \\
Total loans and advances & $79,660.70$ & $91,648.90$ & $106,422.80$ & $124,423.00$ \\
Total SME disbursement to total loans and advances & 38.74 & 27.42 & 30.33 & 22.68 \\
\hline
\end{tabular}

Source: Compiled and calculated by the researchers from the Annual Reports of DBBL, 2011-15. 


\subsection{Green Banking by DBBL}

DBBL, in line with BB's guidelines for environmental management, has been maintaining a balanced initiative and supporting activities to reduce environmental pollution. The bank is engaged in sustainable practices such as efficient use of resources, investment in environment friendly initiatives, effective utilization of its on-line communication system etc. DBBL's environmental management practices reflect the following facts:

a. In-house green management focusing on $3 \mathrm{R}$ thumb rules i.e., reuse, reduce, and recycle in order to reduce environmental pollution. Some of the actions include: using electronic form for internal memos, process notes and records; communicating with customer through emails, SMS or ATM display instead of letter communication (except for regulatory requirements); using Internet Protocol (IP) phone with video conferencing system to communicate with bank officials; and using solar energy as a source of power (as of 2015 the bank set up solar panel to power 50 ATM booths/Fast Tracks and 9 operational branches) [21].

b. DBBL is financing in environmentally complied industries such as waste management project, effluent treatment plant, solar panel setup, automatic brick manufacturing industry, handing waste in a safe manner in hospital, hot water heat recovery system in textile/ready-made garments etc.

c. DBBL maintains the largest on-line banking network supported with state-of-the-art technological innovations and extensively using its on-line facilities.

d. DBBL mobile banking, in a true sense, has been appeared as paperless banking because cash-in, cash out, merchant payment, utility payment, salary disbursement, foreign remittance, government allowance disbursement, and ATM money withdrawal through mobile technology.

e. E-Payment facilities of DBBL is making it easier to purchase online, pay utility bills, tuition fee etc. without having an account and paper notes.

f. The bank has made it a regular practice to allocate fund for capacity building and awareness development of its employees and customers. g. DBBL has active green banking cell consisting of eight members from various divisions to look after the implementation and reporting of green banking initiatives of the bank.

DBBL's green banking initiatives have been creating shared value. The bank is creating environmental value by reducing its footprint through concentrating on technological banking such as mobile banking, e-banking, SMS banking, ATM networks, POS machines, and paperless transactions. The bank is also reducing environmental pollution through investing in selected environmental friendly sectors as mentioned earlier. The bank is also creating social value through CRF and CSR. Every year, DBBL is helping natural disaster vulnerable people living in the coastal zone of the country. Through direct green investment as well as investing in technological banking initiatives, DBBL is also enhancing its business value.

\section{DBBL's Initiatives Along the Three Areas of CSV}

Table 9 shows actions taken by the bank in the three areas of Porter and Kramer CSV concept. At the first area, the bank has reconceived its products and services focusing on less addressed and societal need based products such as agriculture, SMEs including firms of women entrepreneurs, school banking and environment friendly banking among others. These investments options has been fueling the growth of regional economics, protecting environment from negative business decision, and furthering client prosperity. By taking into account of these ever neglected sectors as banking opportunity, the bank is also earning incremental revenue and profits and enhancing customer benefits through innovative services such as online banking, SMS banking, wide own fast track, ATMs and CDM facilities, mobile financial services, card banking, agent banking and other retail banking, thus creating shard value. At the second area, DBBL has taken several measures (shows in Table 9) to enhance productivity growth and operate efficiently. And at the third area, enabling local cluster, DBBL has been creating shared value through sharing wide ATM network with competitors; investing in contract farming; financing in SME clusters etc.

Table 9. DBBL's Initiatives at the Three Areas of CSV.

\begin{tabular}{ll}
\hline Area 1:Reconceiving/Innovating Products and Services(How targeting unmet needs drives incremental revenue and profits) \\
\hline Areas of Effort & Products/Services \\
\hline & 1. Fully Automated Banking Transactions \\
& 2. Online Banking \\
Furthering client access to banking and convenience & 3. Wide ATM Services \\
& 4. Fast Track Services \\
& 5. Mobile Financial Services \\
& 6. Agent Banking \\
\hline \multirow{2}{*}{ Fuelling the growth of regional economics } & 7. Personal Banking \\
Financing solutions to global challenges & 8. School Banking \\
& 9. Card Banking \\
& 10.Other Retail Banking \\
\hline
\end{tabular}


2. Climate Risk Fund (CRF)

3. Environmental Risk Management (ERM)

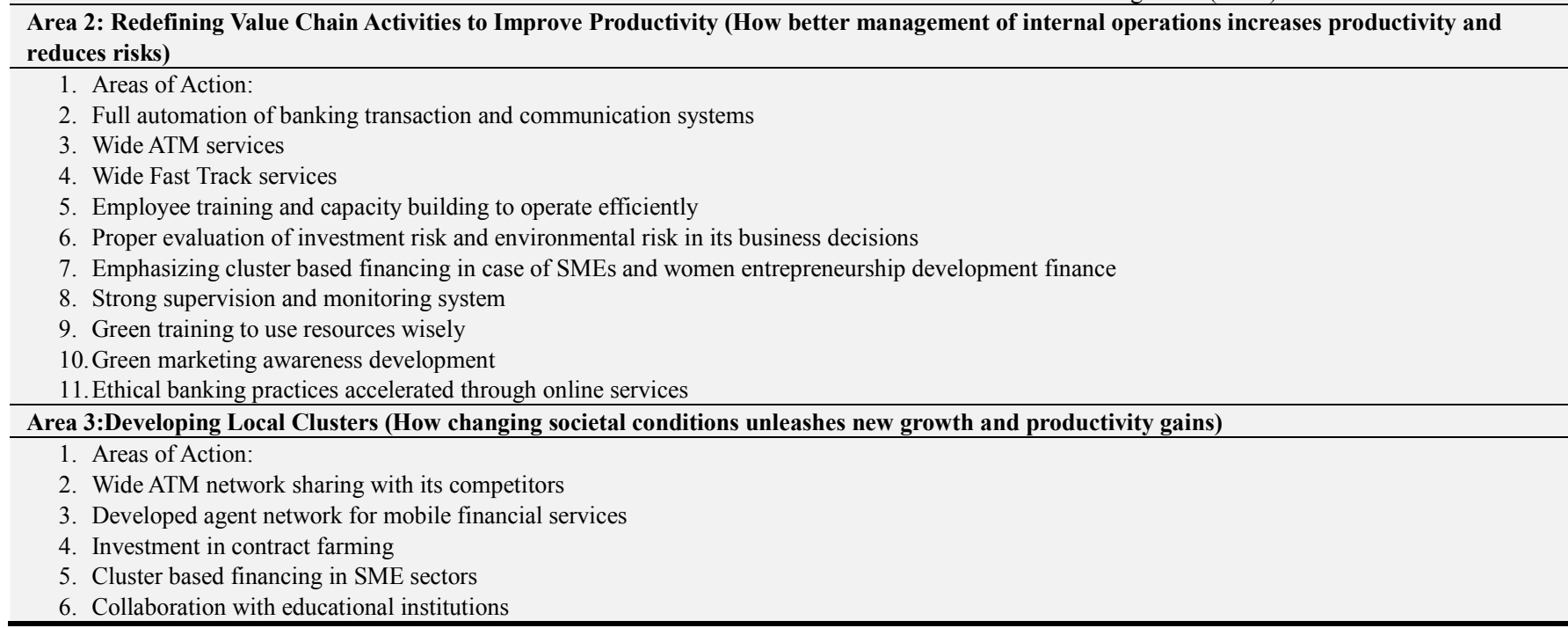

Source: Prepared by the Researchers from Annual Reports of DBBL from 2011-15.

\section{Shared Value of Stakeholders at DBBL}

The following figure summarizes the shared value that has been created by DBBL toward different stakeholders along three dimensions: (1) economic benefits, (2) innovation and knowledge transfer, and (3) social or environmental development issues.

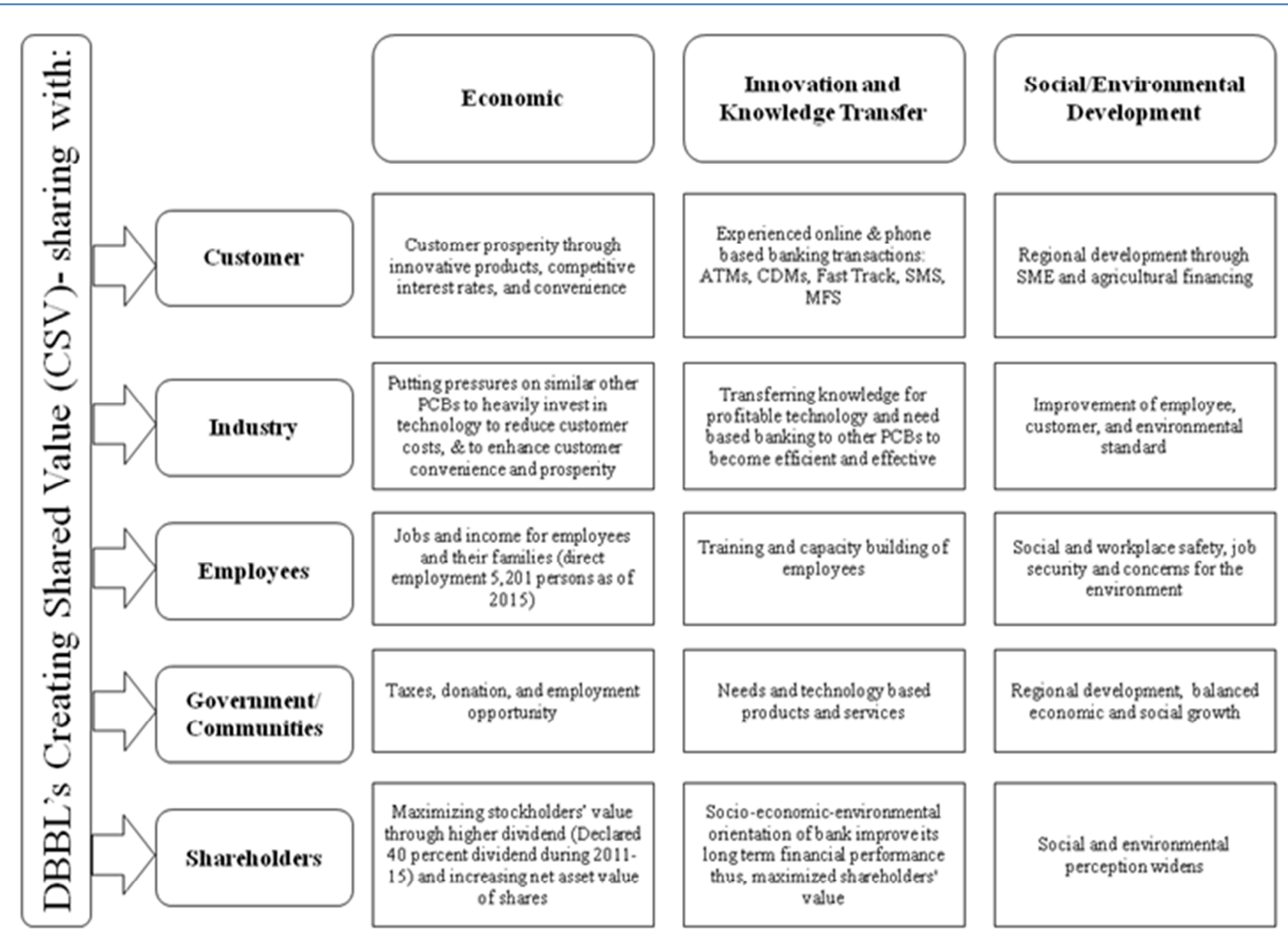

Figure 1. Shared Value Towards Stakeholders at DBBL. 
The above figure delineates that DBBL has been sharing its CSV toward major stakeholders such as customers, industry, employees, government and shareholders. For example, the bank has been creating economic benefits for its customers through innovating need based products, providing competitive lending rates, and ensuring convenience. The bank has been transferring innovation and knowledge to the customers through online and phone based banking transactions. The bank has also been contributing to the regional development of the customers through SME and agricultural lending.

\section{Conclusion}

Balanced economic growth and prosperity of a developing country like Bangladesh largely depends on reducing ruralurban disparity through satisfying unmet or less focused social needs of the neglected sections. The mentionable social needs of the country include but are not limited to "food security, greater financial security, better health, better housing, quality education, improved nutrition, support for the disable and aged, support for the disaster prone communities, support for the agriculture and SMEs, support for the women entrepreneurs, access to formal banking, and environmental protection" [22]. To satisfy these needs and challenges, an appropriate agriculture, SME, environmental risk reduction, women entrepreneurship development, and rural credit policy with institutional and policy support of banks along with government involvement is a must for balanced economic growth and development of the country. It is also necessary to bring the unbanked rural people of Bangladesh into the formal banking network and services to accelerate development. Private Commercial Banks (PCBs) in Bangladesh have mostly expanded their operations in the urban areas and therefore rural people remained isolated from the commercial banking services for so long due to lower token size and high cost transaction. Furthermore, "the PCBs are treating societal issues through philanthropy, which contribute to mitigate some sort of social problems at the expenditure of the stockholders" [22].

DBBL has been creating shared value focusing on less addressed social needs by financing to SMEs including the firms of women entrepreneurs, agriculture, and environment friendly projects; providing mobile financial services that are specially targeted for the unbanked population; and launching in-house environment friendly practices along with other core banking operations. By the inclusion of neglected social needs as banking opportunity, DBBL is providing banking access to the unbanked people, generating direct/indirect employment opportunities, helping distressed and vulnerable people, and reducing environmental footprint among others thus creating shared value. However, these shared value initiatives are not beyond challenges. It is pragmatic that high rate of lending, huge processing costs, unusual delay in sanctioning loans, complexity in documentation and difficulties in providing collateral against loan are the core problems that ceases low savings customers from commercial banking services. Moreover, high operating cost involved in managing greater number of people with from small sized credit, low return expectation, inadequate delivery channel in rural areas, insufficient fund to invest in low profitable areas, high industry competitions, and short term profit mentality ceases banks from creating shared value. Overcoming such barriers to create and cultivate upscale shared value is strongly desirable.

\section{References}

[1] Porter, M. E., \& Kramer, M. R. (December 2006). Strategy and Society: The Link between Competitive Advantage and Corporate Social Responsibility, Harvard Business Review, 84(12), 1-15. http://classes.uleth.ca/200803/mgt3031d/ Porter\%20\&\%20Kramer\%20HBR.pdf.

[2] Porter, M. E., \& Kramer, M. R. (January-February 2011). The Big Idea: Creating Shared Value; How to Reinvent Capitalism - and Unleash a Wave of Innovation and Growth, Harvard Business Review, 1-17. https://businessethics.qwriting.qc.cuny.edu/files/2012/01/Porte r Kramer.pdf

[3] Bockstette, V. \& Stamp, M. (2011). Creating Shared Value: A How-to Guide for the New Corporate (R) Evolution. FSG, 126. https://sharedvalue.org/sites/ default/ files/resourcefiles/Shared_Value_Guide.pdf.

[4] Pfitzer, M., Bockstette, V., \& Stamp, M.(September 2013).Innovating for Shared Value: Companies that Deliver both Social Benefit and Business Value Rely on Five Mutually Reinforcing Elements, Harvard Business Review, 1-10. http://www.philoma.org/docs/2013 2014

Valeur_actionnariale_a partagee/Pfitzer_and_co_-_HBR__Innovating_for_shared_value.pdf.

[5] Porter, M. E., Hills, G., Pfitzer, M., Patscheke, S. \& Hawkins, E. (2012). Measuring Shared Value: How to Unlock Value by Linking Social and Business Results. FSG, 1-15. http://www.fsg.org/tabid/191/ ArticleId/ 740/ Default.aspx?srpush=true.

[6] Maltz, E., Thompson, F., \& Ringold, D. J. (2011). Assessing and Maximizing Corporate Social Initiatives: A Strategic View of Corporate Social Responsibility, Journal of Public Affairs, 11(4), 344-52. doi:10.1002/pa.384.

[7] Waddock, S. (2008). Building a New Institutional Infrastructure for Corporate Responsibility, Academy of Management Perspectives, 22(3), 87-108. doi:10.5465/amp.2008.3458 7997.

[8] Carroll, A. B. (1999). Corporate Social Responsibility: Evolution of a Definitional Construct, Business \& Society, 38(3), 268-95. doi:10.1177/000765039903800303.

[9] Hart, S. L., \& Milstein, M. B. (2003). Creating Sustainable Value, Academy of Management Executive, 17(2), 56-67. doi:10.5465 /ame.2003.10025194.

[10] Aru, S. \& Waldenström, L. (2014). Shared Value Creation for a Profitable Business and Healthy Society: A Multiple Case Study of Swedish SMEs (Master's Thesis). http://lup.lub.lu.se/luur/download?func=downloadFile\&record OId $=4587025 \&$ fileOId $=4587032$. 
[11] Porter, M. E., \& Kramer, M. R. (December 2002). The Competitive Advantage of Corporate Philanthropy, Harvard Business Review, 1-16.

https://sharedvalue.org/sites/default/files/resourcefiles/Competitive_Advantage.pdf.

[12] Aakhus, M. \& Bzdak, M. (2012). Revisiting the Role of "Shared Value" in the Business-Society Relationship, Business and Professional Ethics Journal, 31(2), 23146.doi:10.5840/bpej201231211.

[13] Crane, A., Palazzo, G., Spence, L. J., \& Matten, D. (2014). Contesting the Value of "Creating Shared Value, California Management Review, 56(2), 130-53. doi: 10.1525/cmr.2014.56.2.130.

[14] Dembek, K., Singh, P. \& Bhakoo, V. (2015). Literature Review of Shared Value: A Theoretical Concept or a Management Buzzword? Journal of Business Ethics, 137(2), 231-67.doi: 10.1007/s10551-015-2554-z.

[15] Beschorner, T. (2013). Creating Shared Value: The One-Trick Pony Approach, Business Ethics Journal Review, 106-12. doi:10.12747/bejr2013.01.17.

[16] Williams, R., \& Hayes, J. (January 2013). Literature Review: Seminal Papers on 'Shared value, Oxford Policy Management, $1-27$.

https://assets.publishing.service.gov.uk/media/57a08a47e5274 a31e0000502
/Literature_review_seminal_papers_on_shared_value.pdf.

[17] Lapiṇa, I., Borkus, I., \& Starineca, O. (2012). Corporate Social Responsibility and Creating Shared Value: Case of Latvia. World Academy of Science, Engineering and Technology, 6, 1605-1611. $\mathrm{http} / / /$ waset.org/publications/7540/corporate-socialresponsibility-and-creatingshared-value-case-of-latvia.

[18] Moore, C. (May 14, 2014). Corporate Social Responsibility and Creating Shared Value: What's the Difference? http://www.heifer.org/ partners/corporate-partners/index.html

[19] Bockstette, V., Pfitzer, M., Smith, D., Bhavaraju, N., Priestley, C., \& Bhatt, A. (n.d.). Banking on shared value: How banks profit by rethinking their purpose.

https://sharedvalue.org/sites/default/files/resourcefiles/FSG_B anking\%20on $\% 20$ Shared\%20Value_0.pdf.

[20] Dhaka Stock Exchange Limited (DSE), Listed Companies, Dutch-Bangla Bank, http://www.dsebd.org/displayCompany.php?name= DUTCHBANGLA.

[21] Dutch-Bangla Bank Limited (DBBL) Annual Reports 20112015, Dhaka, Bangladesh.

[22] Rabiul Islam, M. (2017). Banking on Shared Value: A Study on Private Commercial Banks in Bangladesh ( $\mathrm{PhD}$ diss.). Institute of Bangladesh Studies, University of Rajshahi, Bangladesh. 